$$
\text { Banyár József }
$$

\title{
Az önvezető autók lehetséges hatásai az életmódra és a gazdaságra
}

\section{The Possible Effects of Autonomous Cars on Life-Style and on the Economy}

\section{Összefoglalás}

Napjainkra, hosszú kísérletezések után, látható közelségbe kerültünk az önvezetô autók megvalósulásához. Hatásuk azonban várhatóan nemcsak annyi, hogy ezentúl még könnyebb lesz a gépjármúvek vezetése, hanem az élet szinte minden területén alapvetô változásokat hoznak. A cikkben részben a vonatkozó szakirodalom feldolgozása, részben pedig azok továbbgondolása révén, megpróbálunk felvázolni néhány logikus következményt, hogy mi, hogyan és miért változhat meg a gazdaság és társadalom területén közép- és hosszú távon. Kísérletet teszünk annak felvázolására is, hogy Magyarország ezeket a várható tendenciákat hogyan tudja felhasználni a közepes jövedelmi csapdából való kitörésre.

Journal of Economic Literature (JEL) kódok: D31, D91, E21, E22, H41, H54, L62 Kulcsszavak: önvezetô autók, úthálózat finanszírozása, gépjármú-biztosítás, közepes jövedelmi csapda

\section{Summary}

After a long experimental period, self-driving cars (or autonomous vehicles) have become a close reality by now. However, in addition to driving becoming simpler, they will gradually bring fundamental changes in almost every aspect of our life. Partly

Dr. Banyár József PhD, egyetemi docens, Budapesti Corvinus Egyetem (jozsef.banyar@uni-corvinus.hu). 
through an analysis of the relevant literature, and partly by taking it further, in the paper an effort is made at outlining some logical consequences: the changes such cars are expected to bring about in the economy and society over the medium and long run, and their causes. An attempt is also made at outlining the way Hungary can benefit from these trends.

Journal of Economic Literature (JEL) codes: D31, D91, E21, E22, H41, H54, L62

Keywords: autonomous cars, road network financing, motore vehicle insurance, median income trap

\section{BEVEZETÉS}

Amennyiben az önvezetô autók a nem is olyan távoli jövôben valóban megvalósulnak, alapvetôen formálják majd át nemcsak a mobilitásunkat, hanem a szállítás és a foglalkoztatás egész rendszerét is. Valószínúleg nem túlzás azt állítani, hogy az önvezetô autók olyan forradalmat indíthatnak el, amely a gazdaság egészét is átszabhatja. Ugyanakkor az egyes országok között jelentôs eltéréseket tapasztalhatunk az önvezetô autók fejlesztése, társadalmi elfogadottsága, valamint az elterjedéséhez szükséges jogrendszer terén. Számos elemzés készült már az önvezető autók hatásairól, a következókben ezen elemzéseket igyekszünk, elsôsorban Európára koncentrálva, áttekinteni. Az önvezetô autók gazdasági és társadalmi kérdéseire vonatkozó irodalom jó áttekintését adta eddig többek közt Clark et al. (2016), valamint Milakis et al. (2017). Az európai uniós törekvésekról, illetve az EU-val versenyben álló térségek eredményeirôl alapos elemzést készített a European Roadmap Smart Systems for Automated Driving címú összefoglaló anyag, amelyre jelentôs mértékben támaszkodunk a következôk során (Dokic et al., 2015).

Nem meglepó módon, tükrözve az Egyesült Államok vezetô szerepét a robotizáció és speciálisan az önvezetô autók fejlesztése terén, az amerikai National Bureau of Economic Research kutatói is jelentôs gazdasági és társadalmi elemzéseket végeztek az önvezetô autók gazdasági hatásait illetôen (lásd pl. Ostrovsky-Schwarz, 2018). Ugyanakkor fontos kiemelni, hogy az Egyesült Államok és Európa mellett napjainkban Kína is jelentôs fejlesztéseket eszközöl az önvezetô autók terén. ${ }^{1}$ (Sajnos ugyanakkor az önvezetô autókkal kapcsolatos kínai eredmények csak másodkézből származó információk alapján elemezhetôk, mivel a kínai publikációk e téren hiányosak, és sokszor szándékosan alul- vagy felülbecsülik az eredményeiket.)

\section{ELŐZMÉNYEK，DEFINÍCIÓK}

Mielőtt belekezdenénk a téma részletesebb tárgyalásába, mindenképpen szükséges áttekinteni az önvezető autók általánosan elfogadott definícióját. A SAE (Society of Automotive Engineers, SAE), az Amerikai Gépjármúmérnökök Egyesülete 2014-ben 
egy szabvány formájában definiálta az autonóm gépjármúvek terminológiáját, illetve meghatározta azok automatizáltsági szintjeit (SAE, 2014). A Német Szövetségi Útügyi Kutatóintézet (Bundesanstalt für Straßenwesen, BASt), valamint az amerikai egyesült államokbeli Nemzeti Közúti Közlekedésbiztonsági Hivatal (National Highway Traffic Safety Administration, NHTSA) szintén megfogalmazták a maguk nómenklatúráit, ám ezek közt csak minimális eltérések találhatók. Az automatizáltság szintjei alapvetốen azt mutatják meg, hogy a dinamikus vezetési múveletek hogyan oszlanak meg az ember és a gép között (lásd erre nézve pl. Reese, 2016, illetve NHTSA, 2016). ${ }^{2}$

Bár úgy vélhetnénk, hogy az önvezetés a távoli jövơé, amelynek megvalósítása még sok idốt és munkát igényel, a valóság azonban nem pontosan ez. A ténylegesen autonóm, azaz emberi beavatkozást nem igénylô önvezetố autók elterjedése valószínúleg jóval közelebb van, mint ahogy azt gondoljuk. Az önvezetô autók meghatározásáról és kialakulásuk történetérôl többek közt a budapesti múegyetem munkatársai adtak kitúnố elemzést (Takács et al., 2018).

Ugyanakkor napjainkban jelentôs eltérések mutatkoznak az egyes földrajzi régiók, illetve országok közt a tekintetben, mennyire van ott jelen az önvezetố autók koncepciója, valamint hogy mekkora az elfogadottsága. Emellett az önvezetô autók katonai jelentôsége miatt gyakran csak kevesebb információ érhetố el a fejlesztésekról. Ugyanakkor nem véletlen, hogy akárcsak a 20. század elején a hagyományos gépjármúvek terén, Európa e téren is bizonyos lemaradást mutat az Egyesült Államokkal szemben, és napjainkra az önvezetố autók fejlesztésének terén egy új játékos, Kína is megjelent. ${ }^{3}$

Az önvezetố autók előfutáraként az Egyesült Államokban már a húszas években megvalósult egy rádió által távirányított autó (Pontiac Phaeton), majd 1964-ben a New York-i világkiállításon bemutatták a General Motors Firebird nevú, szintén többé-kevésbé önvezetố prototípusát. Ezek közül a Pontiac Phaeton nyilvánvalóan nem önvezetô, inkább távolból irányított autónak tekinthetô, a GM Firebird pedig csak nagyon korlátozott sávelhagyás-figyelmeztetố rendszerrel volt felszerelve. Az elsố számítógép-vezérelt önvezetố autót a Carnegie Mellon University (CMU) Navlab 1 néven mutatta be a nyolcvanas évek közepén. Ez az autó már képes volt egyenes vonalban haladni, és közben akadályokat is kikerülni. Nem meglepó módon a katonaság, pontosabban az internet kifejlesztésében is kulcsszerepet vállaló DARPA finanszírozta a Navlab projektet. Később több hagyományos autógyártó, illetve techcég is beszállt az önvezetố autók fejlesztésébe. Az autonóm, önvezetố autó kifejlesztésén egymástól függetlenül több cég, így a Google, a Nissan ${ }^{4}$ és a Tesla Motors is dolgozott.

Európában a Mercedes Benz, a Müncheni Egyetem, valamint a nyugatnémet Bundeswehr az EU Eureka PROMETHEUS (PROgraMme for a European Traffic of Highest Efficiency and Unprecedented Safety) 1987 és 1995 közt folyó R+D-projekt keretében hozott létre terepjárásra is alkalmas önvezetô gépkocsikat. A projekt 1995ben sikeresen lezárult, olyan prototípusok kialakításával, amelyek képesek voltak automatikus sebességtartásra, sávkövetésre, autók közti információátvitelre, vagyis csupa olyan funkcióra, amelyeket napjaink sorozatban gyártott autói már általában 
tudnak (lásd erról pl. Takács et al., 2018:106-107). Az általuk létrehozott önvezetô autók, a VaMP és a VITA-2 több mint ezer kilométert tettek meg a Párizs körüli Boulevard Périphérique többsávos autóúton, hétköznapi csúcsforgalmi zsúfolt körülmények közt. Ezalatt esetenként 130 km/órás sebességet is elértek, ezzel igazolva, hogy a jármúvek képesek háromsávos autópályán is, akár egyedileg, akár konvojban, rendszeres elôzésekkel és sávváltásokkal is folyamatosan, vezetô nélküli üzemmódban közlekedni.

A Navlab önvezetési rekordját egészen 2015-ig nem döntötték meg, amikor az amerikai autóalkatrész-gyártó cég, a Delphi önvezetô rendszerét beépítették egy Audiba, és ekkor 15 államon keresztül 5472 kilométert vezettek le a kocsival, az út 99\%-át önvezetô módban megtéve. Az Egyesült Államokban Nevadában, Floridában, Kaliforniában, Virginiában és Michiganben, valamint Washingtonban közutakon is engedélyezett már önvezetô autókat tesztelni. Az elsô önvezetô autó autonóm, azaz vezetô nélküli módban 2016. május 7-én okozott halálos baleset, amikor egy Tesla Model S 70D csapódott egy traktornak a floridai 27-es fốton. Ugyanakkor önvezetô autók nem önvezetô, azaz nem autonóm, hanem emberi ellenôrzést igénylô módban már korábban is okoztak balesetet. ${ }^{5}$

Tény, hogy mind a mai napig csak az önvezetô autók alacsonyabb szintjei jelentek meg a közutakon, a ténylegesen autonóm, tehát emberi felügyeletet vagy jelenlétet egyáltalán nem igénylő 4., illetve a SAE szerinti 5. szintet még csak lezárt kísérleti próbapályákon tesztelik a fejlesztôk. Az elôrejelzések szerint azonban a 4., 5. szint, vagyis a teljes vezetô nélküli automatizmussal rendelkezô autók hamarosan kereskedelmi forgalomban is megjelennek.

A következókben önvezetô autók alatt szigorúan a (ma még csak kísérleti szinten létezô) 4. és 5. szintet értjük, azt, amikor már egyáltalán nincs szükség emberi felügyeletre és/vagy beavatkozásra.

\section{ÖNVEZETó AUTÓK VERSUS HAGYOMÁNYOS GÉPKOCSIK}

Abban mindenki egyetért, hogy az önvezető autók képesek lesznek alapvetôen átalakítani a mobilitási szokásainkat, és a gazdaság szervezésének alapelveit is, vagyis egész életmódunkat befolyásolhatják. Míg korábban a gépjármúvek (alapvetôen a lovas kocsik és hintók példáját követve) a használók tulajdonában voltak, és a megvásárlás, valamint a fenntartás költségei szintén a használót terhelték, ma már úgy tûnik, hogy az önvezetô autók esetében ezek a költségek jobban eloszlanak majd a használók és a beruházók közt. Mivel az önvezetô autók kérdése egyre izgalmasabb téma napjainkban, ezek közül is ki kell emelni Surden és Williams elemzését, amely nemcsak a technikai, hanem a jogi és gazdasági aspektusokat is tárgyalta (SurdenWilliams, 2016).

Az önvezetô autók esetében hosszabb távon elképzelhetô a központilag irányított intelligens közlekedési rendszer (ITS) kialakítása is (errôl lásd részletesebben Yuan és Wang cikkét, akik egyenesen a blockchainrendszer megoldásait javasolják a rendszer múködtetésére). Mi most ezekbe az önvezetô autók technikai megoldásait illetô (illet- 
ve az azokkal járó veszélyekkel kapcsolatos) elôrejelzésekbe nem kívánunk belefolyni, inkább a lehetséges gazdasági és társadalmi következményekre fókuszálunk.

\section{A HAGYOMÁNYOS GÉPKOCSIKKAL KAPCSOLATOS ELLENTMONDÁSOK ÉS AZOK FELOLDÁSI KÍSÉRLETEI}

A hagyományos gépkocsik esetében alapvetô ellentmondás, hogy azok, a nevükkel ellentétben (önjáró, azaz auto-mobil) az életük nagy részében egyáltalán nem mozogtak, pláne nem önállóan, hanem fóként egy helyben állnak, azt várva, hogy a tulajdonosaik elôvegyék a garázsból, vagy beüljenek az idô nagy részében az utca szélén parkoló kocsikba. Ez a használati mód meglehetôsen pazarló jellegú, hiszen ha egy autó nem közlekedik, ugyanúgy pénzbe kerül, mintha egész nap mozgásban lenne (meg kell venni, és veszti az értékét azáltal, hogy az újabb modellek megjelenésével folyamatosan avul, ugyanakkor fizikailag is romlik, pl. rozsdásodik is). Ezen a pazarláson már az önvezetố gépkocsik megjelenése elôtt is többféle megoldással igyekeztek segíteni: a gépkocsik bérlésével (car renting); a gépkocsik megosztásával (car sharing); a tömegközlekedés mint alternatíva felkínálásával; egy-egy vállalatnál alkalmazták a közösen használt gépjármúflottát is. A hagyományos, nem önvezető gépkocsik esetében azonban egyik megoldás sem tökéletes, ezért nem is terjedtek el szélesebb körben.

Az autóbérlés nehézségei hagyományos, nem önvezetố autók esetében

Az autóbérlés esetében az egyik legnagyobb problémát az okozta, hogy a gépkocsihasználat rendszerint időben erôsen koncentrálódott. Reggelenként mindenki azonos időben indult dolgozni, délutánonként azonos időben igyekeztek haza, ugyanazon a héten, sôt napon indultak az emberek nyaralni, síelni. Bár a nyaralás koncentráltsága oldódott az idők során, azért a gépjármúvek időbeli használata még továbra is koncentrált maradt. Így aztán jóval több gépkocsira volt igény, mint amennyi átlagosan optimális lett volna, valamint ezek a bérautók a csúcsidôszakon kívül éppúgy álldogáltak valahol, mint a magántulajdonban lévô társaik.

Gondot jelentett, hogy a bérelt gépkocsikat rendszeresen vissza kellett vinni a telephelyre ellenôrzésre és szervizelésre, ami nem könnyítette meg az autók bérlését. Ezt a problémát a bérelt gépkocsikhoz rendelt sofőrökkel részben kiküszöbölték, ez azonban jelentôsen megemelte a bérlés árát, így ez a megoldás csak egy szúk, gazdag réteg számára állt rendelkezésre. További gondokat okozott, hogy a bérlók rendszerint kevéssé gondosan használták a bérelt autókat, mint a saját tulajdonban lévôket, ezért a bérautók élettartama csökkent, állaga romlott, szemben a gépkocsi-tulajdonlással, ahol a tulajdonos-használó tudta, hogy késôbb neki kell majd elszenvednie a kevéssé gondos használatból adódó költségeket.

A gépkocsibérlés csak akkor múködött hatékonyan, amikor a használó nagyobb távolságra utazott el, és nem volt lehetséges és/vagy gazdaságos magával vinni a saját kocsit, pl. egy másik kontinensre való utazás során. 
A car sharing, vagyis a gépkocsik megosztása hagyományos gépkocsik esetében

Megosztás esetén a nehézségeket a fent tárgyaltakhoz nagyon hasonló okok okozzák, ezért általában csak olyankor kerül sor arra, hogy a különbözó tulajdonosok közös gépjármúvel járjanak dolgozni, amikor az üzemanyagárak hirtelen jelentôsen megemelkednek. E nélkül nagyon nehéz rávenni az embereket arra, hogy ne egyedül, esetleg másodmagukkal üljenek autóba. A car sharingnek több formája létezik:

- az önkéntes, ingyenes, eseti, nem szervezett car sharing, mint például a közös munkába járás, illetve a közös hazatérés;

- az önkéntes, ingyenes, eseti, mobilapplikáción keresztül szervezett car sharing;

- egyéb szervezett, de végsố soron nem igazi car sharing megoldások, mint például az Uber.

A fenti car sharing módszerek egy része (pl. az Uber), úgy túnik, kizárólag a taxiszabályozás és az adózás kijátszását szolgálja, és ezért ezeket nem is tekinthetjük valódi car sharingnek. De az „igazi” car sharing esetében is komoly kérdőjel maradt, hol tárolják az autókat, és ki fedezze az autózás költségeit.

Természetesen mind a car sharing, mind a bérlés esetében komoly visszatartó erô volt, hogy az ipari társadalom kialakulása után az emberek egyre inkább tulajdonolni akartak tárgyakat, hogy ezzel is mutassák magas társadalmi szerepüket.

\section{Egyéni autózás versus tömegközlekedés}

Az autók múködésében azon alapvető ellentmondást, hogy egy mobilitásra tervezett és létrehozott eszköz élettartamának nagy részében mozdulatlanul áll, várva, hogy a tulajdonos használja, leginkább a tömegközlekedés igyekezett áthidalni. Az automobilok felhasználása során a tömegközlekedés (a társas kocsik) alkalmazása az egyik legkorábban jelentkezô megoldás volt, amit aztán az autók árának zuhanása és az egyéni szabadság egyre fontosabbá válása erôsen megkérdőjelezett a 20. század során. Egy autóbusz vagy villamos kétségtelenül gazdaságosabb, bár egyértelmúen kényelmetlenebb közlekedési eszköz, mint az egyéni közlekedést szolgáló személyautó, és akkor még az autózás által biztosított nagyobb szabadságot és társadalmi presztízst nem is tekintettük.

\section{Vállalati flotta használata}

A vállalati flották esetében a gépkocsik kihasználtsága jobb lehet, bár ennek akadálya, hogy a vállalati autókat is rendszerint munkaidóben (vagyis reggel 8 és este 6 között) használják, fóként hosszabb távolságokra, ami bizonyos mértékig szuboptimális helyzetet teremtett, hiszen élettartamának legalább egyharmadában (éjjel) a vállalati autók is kihasználatlanok.

Itt is felmerül, hogy az autózás, az autók feletti tulajdonlás társadalmi presztízst is jelent, ami miatt a vállalati flottákat rendszerint csak az alacsonyabb szintú beosztottak 
és esetleg a középvezetôk használják, a felsô vezetôk esetében már sokkal jellemzôbb a személyi használatra biztosított autó (esetleg személyi sofőrrel együtt). Ez ugyanakkor azt is jelenti, hogy minden olyan kiadás, amit egyébként a tulajdonos fedezne, ebben az esetben a vállalatra hárul. ${ }^{6}$

\section{AZ ÖNVEZETő AUTÓK GAZDASÁGOSSÁGA}

Az önvezetô autók esetében alapvetôen más a helyzet, ugyanis a használathoz nem kell előre megvenni az autót, és fôként nem kell folyamatosan a használó közelében tárolni: amennyiben éppen nincs szükség a gépkocsira, el lehet küldeni, és a felhasználási modelltôl függóen

- vagy álljon mások rendelkezésére,

- vagy menjen el önállóan egy, az önvezetô autók számára fenntartott „remízbe”, ahol a rendszer üzemeltetôi feltöltik, karbantartják, szükség esetén kijavítják, illetve a gépkocsit szükségképpen pusztító elemektôl védve tárolják.

Az önvezetố autók esetében tehát megszúnhet az az ellentmondás, amely szerint az alapvetôen mobilitást célzó eszköz élettartamának nagy részében egy helyben vesztegel, ezáltal lehetôvé válhat a szúkös erőforrások észszerúbb (akár folyamatos, 24 órás), gazdaságosabb kihasználása.

Egyéni versus tömegközlekedés, tulajdonlás versus bérlés az önvezetô autók korában

Tömegközlekedés: a vezetô nélküli kocsival potenciálisan eltúnik a határ az egyéni és a tömegközlekedés között, hiszen az egyéni közlekedés eddig elsôsorban a vezetô személyéhez volt kötött. Azonban ha bármikor rendelhetek magamnak kocsit, és az bemondásra elvisz oda, ahova tartok, feleslegessé válik otthon tartani egy saját autót. Ezzel párhuzamosan jócskán csökkenthető olyan buszok üzemeltetése, amelyek sztenderd útvonalon haladnak. Ezek helyett kis méretú, egy-két személyes kocsikat lehet készíteni, amelyeket címre lehet rendelni. Ezek nyilván nem robusztus, sokat fogyasztó jármúvek, még csak jól sem kell kinézniük, csak kényelmesnek és üzembiztosnak kell lenniük. A tömegközlekedés és az önvezetô autók közt azonban nem feltétlenül tekinthetố eldöntöttnek a verseny. Ahogy arra Ralph Buehler felhívta a figyelmet, „a tömegközlekedésnek komoly elônye, hogy sokkal gazdaságosabban bánik a térrel, mint az önvezetô személyautók, és ez igen fontos lehet a zsúfolt belvárosok esetében” (Buehler, 2018:14-16). Emiatt a klasszikus tömegközlekedés olcsóbb maradhat, mint a funkcióit nagyrészt átvevô önvezetô autók, ami különösen az árérzékeny fogyasztók számára lehet vonzó, továbbra is fenntartva a tömegközlekedést igénybe vevő, kevésbé jómódúak és a saját kocsival közlekedó gazdagabbak közti megosztást, csak legfeljebb máshol húzódnak majd a határai.

Bérlés, illetve megosztott használat: Az önvezetô autózás esetében a kocsik tulajdonlásáról eltolódik a hangsúly a bérlés, illetve a sokak általi, megosztott tulajdonlás felé. Emiatt a kocsik költségeinek a szerkezete is megváltozik. Ma az induló magas, fix költség (kocsi megvásárlása) után az autó lassan amortizálódik, ehhez képest 
viszonylag kicsi a változó költségek aránya (üzemanyag, karbantartás). Az önvezetô autóknál a használók esetében kiesik a kezdô fix költség, hiszen ezt feltehetôen a beruházók vállalják át, tehát tôkévé alakul. Ez a szükséges tôke azonban a mostaninál kisebb lesz, mert - mivel az önvezetô autókat el lehet küldeni a központi garázsokba, tároló- és karbantartó helyekre - kevesebb kocsira lesz szükség, mint most, a hagyományos autók korában. ${ }^{8}$ Mindennek többféle vonzata van: egyrészt egyfajta tôkekoncentrációt eredményezhet, hiszen a kocsiban ma benne lévô, de felszabaduló tôke sokakat arra késztet, hogy azt feléljék, másrészt új befektetési lehetôséget teremt a takarékosaknak. Ez lehet a nagytóke része is, de el is lehet osztani azt a lakosság tagjai között. Ilyen szempontból tehát ma még kérdéses, hogy mindez a gazdagság koncentrációját vagy éppen ellenkezóleg, a kocentráció csökkenését vonhatja maga után. Ugyanakkor azt is jelenti, hogy szemben a mai helyzettel, amikor a kocsit rossz hosszú távú befektetésnek tekinthetjük, mert folyamatosan veszít az értékéból, az állandóan megújuló, menedzselt kocsiflottába való befektetés felveszi a klasszikus, hosszú távú befektetés tulajdonságait (egyfajta befektetési alappá válik), így alkalmas lesz pl. nyugdíj-elôtakarékosságra. Az előrelátó emberek ezért ettôl kezdve a nyugdíjtókéjüket (önvezetô) kocsikban (ilyen flottát múködtetô cégekben szerzett tulajdonrész révén) is tarthatják.

\section{A kocsitárolás és parkolás változása az önvezetô autók korában}

Az önvezetô autóknak kisebb garázsok is elegendóek lehetnek, ugyanis elég lesz az utazás céljánál kiszállni, a kocsi parkolásáról már nem szükséges a helyszínen gondoskodni, a kocsi önmaga megoldja a parkolást egy arra alkalmas helyen. Egy ilyen „alkalmas helyen” az önvezetó kocsik akár egymásra is zsúfolódhatnak, ugyanis tetszőleges sorrendben hagyhatják el. Kisebb tárolóhely esetén akár egy bejárat is elegendô, vagyis a logisztika szigorú szabályai szerint LIFO-znak (last in, first out), ami nem szerencsés, mert a belülre szorult kocsik akár sokáig is kimaradhatnak a forgalomból. Ez a szempont azonban csak a nagy tárolóknál lesz lényeges, ahol mindenképpen FIFO-zni kell (first in, first out), vagyis azt jelenti, hogy ezeknek kell lennie külön be- és kijáratának. Hiszen ahhoz nem kell ragaszkodni, hogy az emberhez ugyanaz az autó jöjjön ki, mint ami a legutóbbi használata után bement oda.

Nincs szükség (nagy) parkolókra a plázákban, lakóházakban, de az utcákban sem, vagyis a - most fóleg a parkoló autók miatt - szúk belvárosi utcákban rengeteg hely szabadul fel a közlekedésre, ezzel is lényegesen csökkentve a dugókat. Általában is csökken a parkolásra igénybe vett helyek száma, mert egyrészt csökken az autók átlagos mérete, másrészt ugyanúgy lehet parkoltatni óket, mint a bevásárlókocsikat, ugyanis nem szükséges, hogy minden egyes autóhoz külön hozzáférést nyerjünk, mindegy, hogy melyiket visszük el a parkolóból. Ezzel a jelenleg kihasznál(hat)atlan lyukak is jó parkolóhelyek lesznek. A nagy parkolók szükségtelensége miatt a plázák a külvárosokból visszaköltözhetnek a városközpontokba (illetve visszaépülhetnek a belvárosokba a plázaidôszak elôtt létezô kisebb üzletek, bevásárlóutcák), a bevásárlásokhoz is használhatók lesznek az önvezetô autók, mivel nem lesz szükség parkolóra 
az önvezetô kocsik számára. Ugyanakkor fontos megkülönböztetni egymástól az itt említett parkolókat s azokat a tároló-, karbantartó telepeket, ahol az önvezetô autók karbantartását, esetleg feltöltését végzik (bár ez utóbbit decentralizáltan is meg lehet oldani).

\section{A kocsik méretének és dizájnjának változása}

A kocsik mérete azért lesz kisebb, mert számos esetben egy embernek pl. munkába járni elegendô lesz egyszemélyes kocsit rendelnie a négyszemélyes helyett, így valószínúleg többségbe kerülnek az egy- és kétszemélyes kocsik az állományban. Tehát nemcsak a kocsik száma csökken, hanem a méretük is. A gépjármúvek számának csökkenése természetesen alapvetően csökkenti a parkolóhelyek iránti igényt. Persze a számcsökkenést ellensúlyozza, hogy megnövekszik irántuk a felhasználói igény, ezzel viszont nô a forgalom, mert könnyebben rendelnek az emberek kocsit. Hogy mindennek mi lesz az eredménye az utak telítettségére nézve, még nem tudható. A kocsik méretének csökkenése, a racionálisabb forgalom (előzések hiánya), a kocsik közti követési távolság csökkenése, a kevesebb parkoló autó csökkenti az utak telítettséget, a forgalom növekedése viszont növeli.

\section{A sínek elavulhatnak és feleslegessé válhatnak}

Napjainkban sok ország pénzügyileg támogatja a vasúti közlekedést, mert úgy vélik, hogy

- a vasút az összes közlekedési ágazat közt a legbiztonságosabb;

- azok számára is, akik szellemi vagy fizikai problémáik miatt nem tudnak gépkocsit vezetni, a vasút biztosítja a mobilitást;

- amennyiben egy korábban személygépkocsit vezetô személy a vasutat választja, csökken az utak zsúfoltsága;

- egy utaskilométerre vetítve a vasút a legkevésbé szennyezô közlekedési mód.

Yair Wiseman, neves izraeli szakértô (2018) a cikkében azt állítja, hogy az elóbb felsorolt érvek mind érvényüket vesztik a hálózatba kötött, elektromos hajtású önvezetô autók elterjedésével. A vasutak állítólagos elónyei szerinte az önvezetô, elektromos autók elterjedése esetén gyorsan elolvadnának. A környezetvédelmi szempontok eltúnnek az elektromos meghajtásnál, a mentális és fizikai képességek szintén irrelevánsok lesznek az önvezetô jármúvek elterjedésével, és hasonlóan a városi zsúfoltság problémája is megszúnik az optimalizált önvezetô gépjármúvek esetén. Wiseman következtetése, hogy a vasút kétszáz éves koncepciója nagy valószínúséggel más megoldásoknak adja át a helyét (Wiseman, 2018:156-157).

A magunk részéról ezt nem látjuk ennyire egyértelmúnek, mert a hosszabb utak esetében a vasút megórizheti az előnyét (kényelmesebb egy nagy teremben ülni, mint egy helyben, és menet közben járkálni is), emellett olcsóbb is lehet. A vasút elsôbbsége az autókkal szemben megmaradhat, ha ott is sikerül megoldani az önvezetést, és megvalósítani a szerelvények szétdarabolását, ezzel sûrítve az indulásokat, ami a legfóbb 
kényelmetlenséget jelenti a vasúti közlekedésben. Emellett az önvezető kocsik és a vasút jól kooperálhat: az ember az egyik városban kiviteti magát egy önvezetô kocsival a vasútállomásra, akár közvetlenül a saját vasúti kocsijához, majd a célállomásra odarendelhet egy másik, helyi önvezetô kocsit.

\section{Az önvezetố autók hatása az életmódra}

Csomagszállítás: új ösztönzést kap az elektronikus beszerzés (akár úgy, hogy a hútônk automatikusan rendeli a hiányzó tételeket, amihez persze a hútôt kell úgy kiképezni, illetve a csomagolást is standardizálni) azzal, hogy egyszerúvé válik a kézbesítés. Ehhez már nem kell kézbesítô (amivel viszont újabb állások vesznek el), és az sem szükséges, hogy otthon legyenek. A megrendelt árut egységcsomagokban vezetố nélküli kocsira pakolják, amely elviszi a csomagokat a megfelelő házhoz, ott beteszi óket a megfelelốn kiképzett (ma még nem létezô) csomagpostaládába, amelyet esetleg belsô lift köti össze a lakással és a hútôvel. (Ehhez a hútôket is át kell tervezni, hogy legyen egy „hátsó” ajtajuk a csomagszállítóknak, vagyis az önvezető autók elónyeinek a kiaknázása egy sor más tárgy konstrukcióját is megváltoztathatja.) A megrendelések teljesítése akár ugyanazokkal a kocsikkal is történhet (ha annak konstrukciója kellóen rugalmas), mint amivel a személyszállítás, emellett az áruszállítás éjszakára idôzíthetô, ezzel 24 órássá tehetô a kocsik kihasználtsága, ami jelenleg leginkább a nappali órákra korlátozódik.

Bevásárlás: erôsen csökkenhet (esetleg meg is szúnik) a kocsi azon funkciója, hogy a bevásárolt holmikat azzal szállítjuk haza, általánossá válik ugyanis a csomagküldés. Visszatérünk a száz évvel ezelőtti rutinhoz, hogy a megvásárolt holmit nem hazaviszszük, hanem hazaküldetjük. Emiatt a bevásárlás menete is megváltozik: egy bevásárlókocsiba összekészítjük a megvásárolni kívánt árut, hozzáérintjük a hitelkártyánkat, a többi automatikusan zajlik. Megszúnik a pénztár és a pénztárnál való sorban állás. Igaz, hasonló módon vásárolhatunk ma is az online áruházakban, de sokunknak még fontos, hogy a polcok között keresgéljük az árut, ne online listákban.

A házhoz szállitás is egyszerúbbé válhat, felpörög az internetes rendelés. A házakba rendelésleadó ablakokat építenek, az áruk átvételéhez nem is kell otthon tartózkodnunk. Mindez viszont a maihoz képest rengeteg új forgalmat generál. A kisebb tételeket ezért majd drónokkal érdemes szállítani, vagy talán gazdaságosabb egy autóba egyszerre sok árut pakolni, s csak közvetlenül a célnál, az autóról kihordani a drónnal. A megnövekedett drónforgalmat szintén szabályozni szükséges (pl. az utca fölött 3-4 méterre repülhetnek). A kis drón tehát csak a sok árut tartalmazó kocsi és a végsố célpont között közlekedik. A kocsiban állandó optimumszámítási múveletet futtatnának, hogy az adott legjobb útvonalat megtalálják.

A közlekedés technikájának a megváltozása: akár a városi, akár a közúti (fôleg az autópályán zajló) közlekedésben, miután az autók egymást megelôzni nem fogják, a tartósan egy irányba menô kocsik menet közben összekapcsolódhatnak a megfelelő helyen, miután informálódtak, hogy a többiek merre mennek. Ez ismét hatással lehet a kocsik dizájnjára, még kompaktabbá (s valószínúleg kevéssé esztétikussá) válhatnak. Az utak kvázi sínné alakulhatnak, miután nem kell törôdni az elôzéssel. Az egyetlen problémát 
a kocsiszerelvények szétválása és összeolvadása jelenti a kereszteződéseknél, illetve az egyes kocsik kiválása és becsatlakozása. Ezért az út biztosíthatná az elektromosságot, csökkentve az áram szállítási költségeit; esetleg maga az út is termelhet a felületén elektromos áramot. Egyes kocsikba akár a motor sem szükséges, ha egyébként is összekapcsolódnak; elég egy „motorvonat” egy szerelvényhez.

Mindez erôs ösztönzést jelent a szintbeli keresztezôdések s így a dugók megszüntetésére, a közlekedés felgyorsítására. A kereszteződések kialakítása is egyszerúbb, mert gyengébbek és keskenyebbek lehetnek az utak. Igaz, így a városokban a gyalogosok már nem tudnak átfutni a kocsik között (mely a leggyakoribb balesetforrás), emiatt törekedni fognak az utak és a gyalogosközlekedés szintbeli elválasztására, ami azt jelenti, hogy egybefüggó nagy gyalogos terek alakulnak ki a városokban.

\section{Az önvezetố autók hatása a munkaerô termelékenységére}

Nagyjából egyetértés van abban, hogy az önvezetố autók elterjedése a dolgozók termelékenységére is kedvezó hatással lesz, mivel az emberek nem a vezetésben elfáradva érkeznek majd meg a munkahelyükre (Reese, 2016). Ez különösen azon országok esetében lehet jelentôs, ahol a dolgozók rendszeresen magánautókkal járnak munkába. Ilyen ország például az Egyesült Államok, illetve Nyugat-Európa számos országa, de ez a tendencia a fejlődő országokban is terjedóben van. Nyilvánvaló, hogy amennyiben naponta több tucat kilométert kell sok esetben zsúfolt utakon megtenni, a dolgozó fáradtan, kimerülten és idegesen érkezik meg a munkahelyére, mely befolyásolja a munkavégzését is.

\section{AZ ÖNVEZETó AUTÓK HÁTRÁNYAI - A TELJES ÖNVEZETÉSRE VALÓ ÁTMENET IDÓSZAKA}

Miközben az önvezetô autók komoly előnyökkel rendelkezhetnek, számos hátrányuk is lehetséges, fôleg abban az átmeneti idôszakban, amikor az új és régi technológia egymás mellett múködik. Ebben az időszakban a teljes önvezetés még nem áll rendelkezésre, de az automata rendszerek számos feladatot (sebességtartást, sávkövetést, parkolást) már átvesznek a vezetôtôl. Ez azonban balesetveszélyes, mert a monotónia miatt a vezetô elbambulhat, akár el is aludhat vezetés közben. Ezek a balesetek erôsen visszavethetik az önvezetô autók elterjedését.

Amikor a kocsik már képesek a teljes önvezetésre, de még nem szorították ki teljes egészében a sofőr által vezetett kocsikat, a balesetek szinte kizárólag amiatt történhetnek, hogy a sofôrök a viselkedésükkel (a hirtelen ötlettôl vezérelt manôvereikkel, elôzési szándékaikkal, vagyis azzal, hogy nem „szimulálják” az önvezetô kocsik viselkedését) megzavarják a forgalmat. Ennek következménye lehet, hogy felgyorsul a sofőr által vezetett autók kiszorítása, mely végül a vezetés betiltásához vezethet.

További kritikus pont lehet, hogy az autózás fontos kulturális konnotációt tartalmaz: autót vezetni ma még sok társadalomban presztízskérdés, amirôl feltehetôen sokan nem kívánnak lemondani. Ez azonban a változást csak lassíthatja, a kocsik státusza 
(tulajdonlásukkal és dizájnjukkal együtt) megváltozik, fokozatosan elveszítik státuszszimbólum jellegüket. Persze lehetséges, hogy egy szúk réteg továbbra is megengedi magának a saját tulajdonú önvezetô kocsit, de ezek fennakadásokat okozhatnak, mivel nem tudják igénybe venni azokat a parkolókat, amelyeket kimondottan úgy terveztek, hogy esetleges a gépkocsik kimenó sorrendje.

\section{AZ ÖNVEZETô AUTÓK HATÁSA A GAZDASÁGRA}

\section{Hatásuk a munkaerópiacra}

Az önvezetô autók elterjedésével sok állás elvész: az összes tömegközlekedési sofốri állás, ugyanakkor néhány új keletkezik a flotta menedzselésével kapcsolatos ügyintézésre. A teherautók vezetô nélkülivé válásával megszúnnek a közúti szállítási munkakörök. A teherautók akár a mai formájukat is elveszíthetik, és egyszerú guruló konténerekké válnak egy összekapcsolódó kocsikból álló, alkalmi „szerelvényen” belül.

Nem lesz szükség közlekedési rendőrre sem, a kocsik múszaki ellenôrzését pedig online el lehet végezni. A vezetés betiltása miatt nem indul több vezetôképzés, ezek a vállalkozások is megszúnnek, a fôállású sofơrökkel együtt. Ugyanakkor, amint azt már korábban jeleztük, az autóvezetés megszúnése miatt a dolgozók kipihentebben érkeznek a munkahelyükre, ami növeli a hatékonyságukat és termelékenységüket.

\section{Utak épitésének, karbantartásának finanszírozása, használatarányos útdíj}

Az önvezetô autók korában feltehetôleg megváltozik majd az utak építésének és karbantartásának finanszírozása is. A mai modell szerint - a kevés fizetôs autópálya kivételével - az utakat adókból tartják fenn, gyakran gyenge minóségben. Az utak közjószágok, emiatt mindenki a maximális használatban és a minimális hozzájárulásban érdekelt. Ma már adottak a technikai feltételek ahhoz, hogy pontosan figyeljék és számon tartsák, melyik autó melyik úton, milyen sebességgel, mennyit mozog, vagyis lehetséges lenne személyre szabott, pontos útdijat kiszabni, hogy az teljes mértékben fedezze az utak karbantartását. Ez lenne a sokat emlegetett „használó fizet” elv érvényesítése az utak esetében. Tágabb értelemben ez azt jelenti, hogy megoldható lenne az úthálózat menedzselésében is az eszköz-forrás illesztés, vagyis az, hogy meghatározott célra és annyit szedjenek be a tényleges használóktól, amennyi annak a megfelelô színvonalú fenntartásához szükséges, külsô források bevonása nélkül.

Ezt ma már lehetséges lenne megvalósítani, mégsem teszik meg. Pedig nem biztos, hogy többe kerülne, mint a mai konstrukció, amikor a karbantartást elhanyagolják, majd egyszeri nagyberuházásként radikálisan felújítják. De ha feltételezzük, hogy az új modell összességében mégis többe kerülne, vagyis új pénzeket vonnának be az utak fenntartásába, ez mindent egybevetve csökkentené a fogyasztást. Láthatóvá válna, hogy a mai rendszerben az utak finanszírozása rejtett redisztribúciót tartalmaz a szegényebbek felé, hiszen ók kisebb adót fizetnek, így az adókból finanszírozott jelenlegi modellben ók kevesebbet fizetnek a használatért, mint használatarányos díjak esetén 
történne. Vagyis ez az új finanszírozási modell ugyan arányosabb és méltányosabb, de a mai rendszer rejtett szolidaritását kiküszöbölné a rendszerből.

Miután az önvezetố autók esetében a magánszemélyek összességében nem tulajdonolni, hanem bérelni fogják a kocsikat (kivéve a professzionális felhasználók, pl. a teherautók), elmosódik a határ a kocsi és a tömegközlekedés között. Mivel az előbbi kényelmesebb, sokan váltanának át rá, emiatt összességében megnőne a forgalom és az utak terhelése is. Ellene védekezni az említett, használatarányos útdíjjal lehet, ami megdrágítja az egyéni közlekedést, és olcsóbbá teszi a buszokat, vonatokat, ezzel enyhül a zsúfoltság (mondhatni a szegényeket buszra kényszerítjük a kocsik helyett).

Érdemes megvizsgálni azt is, hogy az önvezetô autók milyen változást okoznak a közgazdaságtanban. A használatalapú útdíj az utak egészen másfajta finanszírozását jelenti, mint a kocsitulajdon és a közösségi finanszírozású út. Másképp takarékoskodik az ember, ha közvetlenül az útért fizet, mintha annak nagy részét már elôre kifizette a kocsi árában. Még a benzinnel teli tank is pazarlásra ösztönöz, mint minden olyan konstrukció, ahol a felhasználás és a fizetés elválik egymástól (Thaler-Sunstein, 2011).

Az önvezetó autók hatása a biztositási piacra

A gépjármú-felelôsségbiztosítás az egyik legnagyobb biztosítási részpiac szerte a világon. Az önvezetố autók egyik hatása a gépjármúbalesetek radikális csökkenése lehet, hiszen a jövốben - legalábbis a teljes önvezetés megvalósulása után - ennek okai csak múszaki hibák lehetnek. Ezért a gépjármú-felelôsségbiztosítás (az eddigi felelôs vezetố hiányában) átalakul termékfelelôsségi biztosítássá, és összegében a töredékére csökken, magával vonva a biztosítói apparátus radikális csökkenését is. De nemcsak a felelôsségbiztosítás csökkenne látványosan, hanem a casco is, mert a kocsik nem törnek össze, nem lopják el, miután nem lesz egyéni piacuk, és magukban a (vagy közlekedô, vagy biztonságos telepen, nem az utcán parkoló) kocsikban sem lesznek különösebb értékek, amely miatt érdemes lenne feltörni óket (az önvezetố autókkal kapcsolatos biztosítási és jogi kérdésekrốl lásd pl. Schellekens, 2015; Glancy, 2015).

\section{AZ ÖNVEZETô AUTÓK TÁGABB TÁRSADALMI HATÁSAI}

\section{Az autók használatának változása és ennek hatásai}

Összességében valószínúleg a kocsihasználat emelkedése várható, visszatartó erô lehet viszont - szemben a mai modellel, amikor az egyszeri, nagyobb befektetés után az amortizációt nem kell azonnal a folyó fizetésből finanszírozni, csak az üzemanyagot az azonnal megjelenô használati költség, az útdíj és az üzemanyag ára. A kiterjesztés irányába hat azonban, hogy sok ma még felmerülő probléma megoldódhat az önvezetố autók elterjedésével. Az idôsek, akik ma már nem tudják használni a kocsikat, ezt ismét megtehetik. Megnôhet a vidéken dolgozók és az onnan ingázók aránya. Elkép- 
zelhetôk irodának, tárgyalóteremnek, hálófülkének berendezett kocsik. Lehetséges lesz a tárgyalásokat iroda helyett a kocsiban tartani, a kocsi csak egyszerúen tesz egy kört közben. Ha a munkába való bejárással töltött idôt akár olvasásra, tévézésre fordíthatjuk, akkor nem lesz igazán jelentôsége, hogy a munkahelyünkhöz közel lakjunk, ez pedig új ösztönzést ad a nagyvárosokból való kitelepüléshez is, vagyis akár a települések is sokkal decentralizáltabbá válhatnak.

\section{További társadalmi hatások, egészségügyi hatások}

Mivel megszúnnének vagy legalábbis drasztikusan csökkennének a közúti balesetek, lecsökkenne a szervdonorok száma is, hiszen a tapasztalatok szerint a gépkocsi-, motorbalesetek áldozatai rendszerint fiatalabb emberek, akik ma a szervátültetések megfelelő donorjai. A további lehetséges társadalmi hatás az alkoholizmus emelkedése, hiszen a vezetés már nem tartja vissza az embereket, sôt kifejezetten adja magát, amelynek megtiltására nem lesz nyomós érv. Megoldást kell találni arra a kérdésre is, hogy mi lesz a fiatalok sebességszükségletével? Esetleg a fiúk visszaszoknak a lovaglásra, amit korábban átengedtek a lányoknak? Miután az autó státusszimbólum jellege feltehetôen megszúnne, nem lenne lényeges az autók külseje. A sportautók megmaradnának az ipari rezervátumokban és talán a fejletlen országokban.

\section{A vezetés jövôje}

Valószínúleg a jövooben vezetni csak a barbár országokban fognak, s azokban a „múvelt” országokban, ahonnét van közlekedés a barbár országokba. Emiatt lesz egy újfajta turizmus: az emberek elmennek elmaradott országokba csak azért, hogy ott saját maguk vezethessenek. Ez egyfajta „katasztrófaturizmus” jellegú tevékenység lehet majd.

\section{A TOVÁB BFEJLŐdés TÁVLATAI}

Elképzelhetô, hogy a távolabbi jövô önvezetô autói akár beépített üléseket sem tartalmaznának, hanem olyan mozgó ülésekkel szerelik fel óket, amelyekbe pakolni is lehet. Tehát egy rövid távon mindenki ülve közlekedik (pl. a szobája és a rendelt kocsi között), majd az üléssel együtt beszáll a kocsiba, kiszáll a reptéren, a motoros üléssel együtt beszáll a repülőgépbe, ami egyben a repülőgép ülése lesz, mivel azon szintén hiányoznak az ülések. Az önvezetô autók üléselrendezésére vonatkozóan lásd pl. Mohamed Elbanhawi, Milan Simic és Reza Jazar elgondolkodtató cikkét (Elbanhawi et al., 2015).

\section{AZ ÖNVEZETŐ AUTÓK EGÉSZSÉGÜGYI KÖVETKEZMÉNYEI}

A teljesen autonóm, mozgó üléseket tartalmazó autók esetében komoly veszélyt jelenthet a mozgásszegény életmód miatti izomleépülés, amit nyilvánvalóan jól szervezett sporttevékenységekkel kell majd ellensúlyozni. Ez olyan új tevékenységeket vetíthet 
előre, amelyeket ma még elképzelni sem tudunk, de valószínúleg ez komoly munkaerôpiaci következményekkel jár majd.

\section{ATtitúdöK ÉS AZOK VÁltozÁsA A ROBOTOKKAL, ILLETVE AZ ÖNVEZETó AUTÓKKAL SZEMBEN}

\section{Attítúdök az egyes európai országokban}

Fontos megnézni, hogy milyen érzelmi attitúdök léteznek az egyes országokban a robotokkal, illetve az önvezetô autókkal kapcsolatban, illetve azt, hogyan változnak ezek az attitúdök, ugyanis az új kutatások irányultságát, illetve az új eredmények elterjedését, gazdasági hasznosítását nagymértékben meghatározzák ezek az értékrendszerbeli és attitúdbeli tényezôk.

Gnambs és Appel (2018) cikkükben annak a kutatásnak az eredményeit ismertették, amelyet 2012 és 2017 közt az EU 27 országában összesen 80396 fốre kiterjedô, reprezentatív vizsgálat során végeztek három hullámban. A legfontosabb megállapításaik a következôk voltak:

- 2012 és 2017 között a robotok megítélése romlott,

- ezen belül a munkahelyi tevékenységeket segító robotok megítélése romlott a leginkább,

- legmarkánsabb az alacsonyabb képzettségú nôk esetében volt negatív irányú változás,

- azon országokban, ahol az idósek aránya magasabb, kevésbé volt erôs a robotok elutasítása.

Nyilvánvaló, hogy a robotok elutasítása erôsen összefüggött a munkahelyek féltésével, és mivel a kutatást nem sokkal a gazdasági válságot követôen végezték, ez az attitûd erôsödött is. Ahogy írták, a „robotizációval szembeni negatív attitúdök, illetve azok erôsödése figyelmeztetően kell hogy hasson a politikai stakeholderekre" (GnambsAppel, 2018:20). Európában (de feltehetóleg általában a fejlett ipari országokban) a robotizáció, illetve az önvezető autók kérdése az emberek attitúdjeiben gyakran öszszekapcsolódik, mivel bizonytalan, hogy a robotizáció következtében megszúnó állásokat más területeken pótolni tudják, ezért a munkahelyek elvesztésétôl való félelmet rávetítik az önvezetô autók kérdésére is, melyet még erôsít a balesetektôl való (mint láthattuk, gyakorlatilag indokolatlan) félelem is.

\section{Attitúdök az önvezetô autókkal szemben Kínában}

Érdekes, hogy alapvetôen eltérô attitûdök figyelhetôk meg Kína fejlett régióiban, mint Európában. Egy 2018-ban Guangzhou Cityben végzett kutatás szerint a válaszolók 99\%-a ismerte az intelligens önvezetô autók jellemzőit (ezek 45\%-a az internetrôl szerzett ismereteket), ugyanakkor a válaszolók jelentôs része a biztonsági tényezókkel kapcsolatos aggodalmát is kifejezte. A válaszolók 70\%-a ugyanakkor nem bízná magát teljesen az önvezetô autókra, bizonyos fokú ellenôrzô funkciókat szeretne magának 
megtartani. Másrészt viszont a válaszadók 94\%-a lett volna hajlandó olyan intelligens autókat vásárolni, amelyek rendelkeznek bizonyos önvezetô funkciókkal, és még magasabb árat is fizettek volna érte. Ez alapvetôen jelzi, hogy Kínában az intelligens önvezető autók piaca jelentôs lesz a jövôben. Ugyanakkor fontos lesz meggyôzni a vásárlókat az önvezetô autók biztonságosságáról.

Érdekes, hogy a robotok miatti munkahelyelvesztéssel kapcsolatos félelmek nemigen merültek fel Kínában, feltehetôen azért, mert a kínai gazdaság dinamikusan fejlődött a vizsgált idôszakban, és folyamatosan vont be újabb és újabb dolgozókat a termelésbe.

\section{AZ ÖNVEZETó AUTÓK MINT KITÖRÉSI LEHETÓSÉG A „KÖZEPES JÖVEDELMI CSAPDÁBÓL”}

Az önvezetó autók fejlesztése rohamléptekkel halad a világban, ami egyúttal azt is jelenti, hogy mindazoknak, akik be akarnak szállni, a legfejlettebb elektronikai, mechanikai, rendszerszervezési, ITC-technológiai ismeretekkel kell rendelkezniük. Jelenleg az önvezetô autók fejlesztése elsôsorban a fejlett centrumországokban (Nyugat-Európa, Észak-Amerika) folyik, bár amint azt már jeleztük, számos jel szerint Kína is igyekszik felzárkózni ehhez a folyamathoz. Kína esetében az önvezetô autók fejlesztése fontos kitörési pont lehet.

\section{Az új típusú globalizáció megjelenése, a nemzetközi vállalatok földrajzi optimalizációja}

A 20. század utolsó harmadában a hagyományos globalizációs folyamat alapvetóen átalakult, és míg korábban a külkereskedelem és a nemzetközi munkaerômozgás felgyorsulása jellemezte, a 20. század hetvenes-nyolcvanas éveitôl kezdve mindinkább a transznacionális vállalatok dominálták. Ekkoriban már a tôke nemzetközi mozgása, azon belül is elsôsorban a külföldi múködőtôke-beruházások (vagyis az olyan nemzetközi tôkemozgások, amelyek révén a külföldi beruházók meghatározó szerepet nyertek a külföldön létrehozott leányvállalataikban) váltak dominánssá, amelynek nyomán a nemzetközi kereskedelmen belül a vállalaton belüli külkereskedelem vált meghatározóvá. Ez azt jelenti, hogy szemben a korábbi évekkel, nem önálló vállalatok közt folyt a külkereskedelem, hanem sokkal inkább a nemzetközi vállalatok különbözô egységei közt. A globális transznacionális vállalatokon belül az internet, valamint a globális vállalati stratégiák megjelenése lehetôvé tette a tevékenységek részekre bontását, és a közlekedés és szállítás olcsóbbá, gyorsabbá válása nyomán lehetôvé vált a termelőtevékenység egyes elemeinek földrajzi terítése, vagyis hogy az úgynevezett „értéklánc” egyes elemeit különbözô országokba telepítsék ki a nemzetközi vállalatok. Erról a folyamatról vállalatgazdasági szempontból számos elemzés és tankönyv is készült (lásd pl. Lasserre, 2012).

A transznacionális vállalatok tevékenységét ettől kezdve egyre inkább az értéklánc egyes elemeinek földrajzi optimalizációja határozta meg: az egyes tevékenységeket a nemzetközi vállalatbirodalmon belül azon leányvállalatokba szervezték, amelyek- 
nek ezáltal valamilyen gazdasági előnye származott. A kilencvenes éveket követően az újonnan átalakult, volt szocialista országok igen vonzó beruházási célpontot jelentettek, ugyanis ott bővében rendelkezésre állt a fegyelmezett és jól képzett munkaeró, a bérek alacsonyak, a szakszervezetek pedig gyengék voltak, emellett földrajzilag nem feküdtek olyan távol a nyugat-európai centrumterületektôl, mint az ázsiai vagy latin-amerikai fejlődő országok. Ennek következtében ideálisnak látszott, hogy 1990 után a nyugat-európai multik az alacsony hozzáadott értékú feldolgozóipari tevékenységüket telepítsék ki az európai volt szocialista országokba.

A nemzetközi vállalatgazdasági szakirodalomban gyorsan elterjedt az a nézet, hogy a termelésen belül a hozzáadott érték alapvetôen attól függ, hogy az egyes elemek hogyan kapcsolódnak egymáshoz, és ennek során kiderült, hogy míg egyfelől a tervezés, a pénzügyi irányítás, a marketing és az értékesítés viszonylag nagyobb hozzáadott értéket előállító tevékenység, addig az egyszerú feldolgozóipari összeszerelés ennél sokkal alacsonyabb hozzáadott értéket hordoz.

\section{A közepes jövedelmi csapda és az új típusú globalizáció kapcsolata}

A közepes jövedelmi csapda szorosan összefügg a globalizáció új hullámával ${ }^{9}$ és a transznacionális vállalatokkal. A közepes jövedelmi csapda azt írja le, hogy a fejlódő országok viszonylag könnyen eljutnak egy közepes jövedelmi szintre, de aztán ott rendre megragadnak (lásd erre vonatkozóan pl. Gill-Kharas, 2015 elemzését). Ez valószínúleg összefügg a transznacionális vállalatok globális földrajzi optimalizációs tevékenységével: nyilvánvaló, hogy amikor egy nemzetközi vállalat néhány tevékenységet (vagyis értékláncának alacsony hozzáadott értéket termelô részét) kitelepít egy elmaradott, olcsó bérszínvonalú országba, akkor egy ideig gyors növekedést indukál az illetố országban, növelve a foglalkoztatást, és új termelési technológiákat honosítva meg ott. Azonban egy bizonyos szint után a transznacionális vállalatnak már nem éri meg további magasabb szintú, magasabb hozzáadott értékú tevékenységet az illetô országba telepíteni, hiszen erre már megvannak a kapacitásai azon országokban, amelyek már korábban kialakították ilyen jellegú tevékenységeiket (lásd erre vonatkozóan pl. Csath, 2019). ${ }^{10}$ Egyre gyakrabban merül fel, hogy a közép-európai országok (Magyarország, Szlovákia, Románia és Csehország) a közepes hozzáadott értékú feldolgozóipari tevékenységektől való, túlzott egyoldalú függésbe kerültek (pl. a hagyományos autógyártás). Ebben a helyzetben, úgy túnik, alapvetô paradigmaváltás nélkül ezek az országok (köztünk hazánk is) képtelenek kijutni a „közepes jövedelmi csapdából”.

Kitörés az önvezetô autók fejlesztésében való részvétellel

A kitörés (egyik) útja éppen az önvezetô autók fejlesztése lehet, és ez azért is fontos, mert az az önvezetố autók fejlesztése során egyszerre van szükség szoftverek, érzékelőrendszerek, akkumulátorok, elektromotorok és egyéb automatikus beavatkozást segítô rendszerek stb. fejlesztésére. Ezek a tevékenységek azonban már nem egyszerú, alacsony hozzáadott értékú, olcsó bérú munkásokat igénylô tevékenységek, éppen 
ellenkezóleg, olyan magas hozzáadott értékú tevékenységek, amelyek magasabban képzett és jobban fizetett munkaerôt igényelnek. E fejlesztési irány további elônye lehet, hogy nem áll túlzottan távol a már eddig is meglévô gépjármúipari technikai munkakultúrától, tehát az ilyen irányban történô elmozdulás nem jelent feltétlenül új ismeretek és képességek megtanulását, hanem a már korábban meglévô képességekre lehet építkezni.

Hazánkban is megkezdôdött az önvezetô autókhoz kapcsolódó tevékenységek kormányzati támogatása. A Zalaegerszeg melletti tesztpályát kifejezetten azért hozták létre, hogy az önvezetô autók fejlesztését segítsék. 2018-ban Grazban, a közlekedési miniszterek konferenciáján „Palkovics László elmondta, hogy Magyarország élen jár abban, hogy olyan technológiát kutatnak és fejlesztenek a cégek, amelyek az önvezetô autók irányába mutatnak. Két éve ezért is döntött úgy a kormány, hogy létrehoz egy világszinten egyedülálló tesztkörnyezetet, aminek a központi eleme a zalaegerszegi tesztpálya. Az önvezetó jármúvek fejlesztésében Magyarország együttmúködik Ausztriával és Szlovéniával is, mert egyebek mellett azt is vizsgálni szeretnék, hogy határátlépés esetén hogyan viselkedik a jármú” (Világgazdaság, 2018). Mindebből az következik, hogy Magyarország esetében az önvezetố autók nemcsak a közlekedést, valamint a mindennapi életünket lesznek képesek megváltoztatni, hanem - amennyiben okosan hasznosítjuk energiáinkat és eróforrásainkat - az önvezetô autók fejlesztése révén jelentôs technológiai ugrást is megvalósíthatunk, amelynek következtében kijuthatunk a gazdasági fejlődést hosszabb távon gátló „közepes jövedelmi csapdából” is.

Ehhez azonban nagyon tudatos fejlesztésekre van szükség, és komoly beruházásokat kell végezni az emberi tôke, mindenekelőtt az oktatás terén, hogy rendelkezzünk majd megfelelő szakemberekkel, akikre stratégiát lehet építeni. És természetesen elengedhetetlen lesz a dolgozók bérének emelése, megbecsülése is, különben a kiképzett szakemberek külföldre távoznak.

\section{JEGYZETEK}

1 Jelen tanulmányhoz az elsố inspirációt a The Economist 2012. október 20-i, gondolatébresztố cikke adta (The Economist, 2012). A tanulmány nem jöhetett volna létre Árva László önzetlen és sokoldalú segítsége nélkül.

2 Az önvezetố autók általánosan elfogadott, SAE és NHTSA által megadott besorolása a következô: 0. szintre jellemzô, hogy nincs önvezetés, itt a gépkocsivezetô végez minden autóvezetéssel kapcsolatos tevékenységet; 1. szint esetében néhány vezetéssel kapcsolatos tevékenység automatikusan szabályozott (pl. szervoféket alkalmaznak, illetve az autó elektronikus stabilitáskontrollal rendelkezik); 2. szint esetében legalább két elsốdleges tevékenységet automatikusan oldanak meg; 3. szint a korlátozott önvezetô autó, amikor az autó bizonyos feltételek mellett képes önvezetésre, de a vezetô szükség szerint átveheti az irányítást a gépkocsitól; 4. szint a teljes önvezetést (a SAE esetében a „magas szintú önvezetést”) jelenti, ekkor a vezetố teljesen feleslegessé vált; 5 . végül a SAE esetében ez a teljesen autonóm, emberi beavatkozást nem igénylô önvezetés. Az eltérés ott van, hogy a SAE eggyel több szintet határozott meg, mint az NHTSA.

3 Bár idônként komoly tudósítások is felbukkannak a kínai önvezetố autókkal kapcsolatban, mind ez idáig (2019 végéig) eléggé ellentmondó hírek érkeztek a kínai önvezetô autókról, ami a kérdés katonai jelentôsége miatt nem is meglepô. Kína mellett ugyan kisebb intenzitással, de azért folynak kezdeményezések az önvezetô autók fejlesztése terén más távol-keleti országokban is. 


\section{Banyár József: Az önvezetô autók lehetséges hatásai az életmódra és a gazdaságra}

4 A Nissan és a Renault tulajdonosi kapcsolódása miatt az európai Renault hamarosan beléphet az önvezetô autók gyártásába.

5 Sajnos a pontatlan sajtóközlemények miatt nem egyértelmú, milyen módban közlekedtek adott esetben az önvezetô autók: úgy látszik, hogy a teljes autonóm, ember jelenlétét nem igénylő önvezetés kora még nem jött el, mindenütt megkövetelik az emberi felügyeletet vagy legalábbis a jelenlétet.

${ }^{6}$ Az önvezetô autókhoz kapcsolódó pszichológiai ellentmondásokról és nehézségekrôl kiváló elemzést készítettek Azim Shariff és munkatársai (Shariff et al., 2017).

7 Több szerzô egyenesen az egyéni közlekedés végét vizionálja, vagyis az önvezetô autók elterjedését követôen nem lesz már egyéni autózás magántulajdonban levô autókkal, hanem minden autó már csak bérlet révén, mintegy közösségi közlekedési eszközként fog múködni.

8 Persze itt több hatás eredője lesz a végeredmény. A kocsik nagyobb kihasználtsága miatt csökken azok száma, de a feltehetôleg megnövekedett kereslet növelôleg hat. A kocsik átlagosan kisebbek és egyszerúbbek lesznek, ami ugyancsak csökkenti a költségeiket, az önvezetố technika maga azonban - legalábbis ahogyan azt ma látjuk - nagyon drága, ami viszont megnöveli azt.

$9 \quad$ A globalizáció új hullámát hiperglobalizációnak vagy neoglobalizációnak is nevezik.

10 Amennyiben egy fejlôdô országban a bérek gyorsabban nônek, mint ahogy azt a multik elfogadhatónak tartják, rendszerint az egész tevékenységet áthelyezik egy másik, olcsó bérszínvonalú országba. Ez történik napjainkban a béremelkedéseket követôen Magyarországon is, amire jó példa a svéd Electrolux részleges kivonulása a jászberényi üzembôl.

\section{FELHASZNÁLT IRODALOM}

Árva, László (2018): Economic and Technical Factors Behind the Rise and Fall of Economic Globalization and Some Consequences in Hungary. A Historical Perspective. Polgári Szemle/Civic Review, Vol. 14, Special Issue, 275-289, https://doi.org/10.24307/psz.2018.0418.

Árva László - Csath Magdolna - Giday András (2018): A hazai kisvállalkozások megerôsítése a neoglobalizáció kihívásaival szemben. Pénzügyi Szemle, 63. évf., 4. sz., 537-555.

Buehler, Ralph (2018): Can Public Transportation Compete with Automated and Connected Cars? Journal of Public Transportation, Vol. 21, No. 1, 7-18, http//dx.doi.org/10.5038/2375-0901.21.1.

Clark, Ben - Parkhurst, Graham - Ricci, Miriam (2016): Understanding the Socioeconomic Adoption Scenarios for Autonomous Vehicles: A Literature Review. University of the West of England, Bristol, http://eprints. uwe.ac.uk/29134.

Csath Magdolna (2019): Közepes jövedelmi csapda vagy fejlettségi csapda és a költségvetési hatások. Pénzügyi Szemle, 64. évf., 1. sz., 29-48.

Derikx, Sebastian - De Reuver, Mark - Kroesen, Martin (2016): Can Privacy Concerns for Insurance of Connected Cars Be Compensated? Electronic Markets, Vol. 26, No. 1, 73-81, https://doi.org/10.1007/ s12525-015-0211-0.

Dokic, Jadranka - Meyer, Gereon - Müller, Beate (2015): European Roadmap Smart Systems for Automated Driving. EPoSS, Berlin.

Elbanhawi, Mohamed - Simic, Milan - Jazar, Reza (2015): In the Passenger Seat: Investigating Comfort Measures in Autonomous Cars. IEEE Intelligent Transportation Systems Magazine, Vol. 7, No. 3, 4-17, https://doi.org/10.1109/mits.2015.2405571.

Gao, Paul - Hensley, Russell - Zielke, Andreas (2014): A Road Map to the Future for the Auto Industry. McKinsey Quarterly, October.

Giday András - Árva László (2018): A méretfüggố vállalati adózás. A kkv-k megvédése a globalizáció negatív hatásaitól. Polgári Szemle, 14. évf., 1-3. sz., 180-192, https://doi.org/10.24307/psz.2018.0814.

Gill, Indermit S. - Kharas, Homi (2015): The Middle-Income Trap Turns Ten. Policy Research Working Paper, No. 7403, https://doi.org/10.1596/1813-9450-7403.

Glancy, Dorothy J. (2015): Autonomous and Automated and Connected Cars - Oh My! First Generation Autonomous Cars in the Legal Ecosystem. Minnesota Journal of Law, Science and Technology, Vol. 16, No. 2. 


\section{Polgári Szemle · 15. évfolyam 4-6. szám}

Gnambs, Timo - Appel, Markus (2018): Are Robots Becoming Unpopular? Changes in Attitudes Towards Autonomous Robotic Systems in Europe. Computers in Human Behavior, Vol. 93, 53-61, https://doi. org/10.1016/j.chb.2018.11.045.

Howard, Daniel - Dai, Danielle (2013): Public Perceptions of Self-driving Cars: The Case of Berkeley, California. University of California, Berkeley.

Johansson-Stenman, Olof - Martinsson, Peter (2006): Honestly, Why Do You Drive a BMW? Journal of Economic Behavior and Organization, Vol. 60, No. 2, 129-146, https://doi.org/10.1016/j.jebo.2004.08.006.

Johansson, Rolf - Nilsson, Jonas (2016): Disarming the Trolley Problem - Why Self-driving Cars Do Not Need to Choose Whom to Kill. Conference paper, Workshop CARS 2016 Critical Automotive applications: Robustness \& Safety, September.

Kohl, Christopher - Mostafa, Dalia - Böhm, Markus - Krcmar, Helmut (2017): Disruption of Individual Mobility Ahead? A Longitudinal Study of Risk and Benefit Perceptions of Self-Driving Cars on Twitter. Conference Paper, 13th International Conference on Wirtschaftsinformatik, February.

Lari, Adeel et al. (2015): Self-Driving Vehicles and Policy Implications: Current Status of Autonomous Vehicle Development and Minnesota Policy Implications. Minnesota Journal of Law, Science and Technology, Vol. 16, No. 2.

Lasserre, Philippe (2012): Global Strategic Management. Palgrave Macmillan, New York, https://doi. org/10.1007/978-1-137-01549-5.

Lee, Eun-Kyu et al. (2016): Internet of Vehicles: From Intelligent Grid to Autonomous Cars and Vehicular Fogs. International Journal of Distributed Sensor Networks, Vol. 12, No. 9, https://doi.org/10.1177/ 1550147716665500.

Milakis, Dimitris - Van Arem, Bart - Van Wee, Bert (2017): Policy and Society Related Implications of Automated Driving: A Review of Literature and Directions for Future Research. Journal of Intelligent Transportation Systems, Vol. 21, No. 4, 324-348, https://doi.org/10.1080/15472450.2017.1291351.

NHTSA (2016): National Highway Traffic Safety Administration. Preliminary Statement of Policy Concerning Automated Vehicles. www.nhtsa.gov/About+NHTSA/Press+Releases/U.S.+Department+of+Transportation+Releases+Policy+on+Automated+Vehicle+Development.

Ostrovsky, Michael - Schwarz, Michael (2018): Carpooling and the Economics of Self-driving Cars. NBER Working Papers, No. 24349, National Bureau of Economic Research, https://doi.org/10.3386/w24349.

Pandi, Sreekrishna et al. (2016): Joint Design of Communication and Control for Connected Cars in 5 G Communication Systems. Global Communications Conference (GLOBECOM), IEEE Press, New York, https://doi. org/10.1109/glocomw.2016.7848940.

Reese, Hope, (2016): Autonomous Driving Levels 0 to 5: Understanding the Differences. Tech Republic, 20 January, www.techrepublic.com/article/autonomous-driving-levels-0-to-5-understanding-the-differences / .

SAE (2014): Automated Driving. Society of Automotive Engineers, www.smmt.co.uk/wp-content/uploads/ sites/2/automated_driving.pdf.

Schellekens, Maurice (2015): Self-driving Cars and the Chilling Effect of Liability Law. Computer Law and Security Review, Vol. 31, No. 4, 506-551, https://doi.org/10.1016/j.clsr.2015.05.012.

Shariff, Azim - Bonnefon, Jean-Francois - Rahwan, Iyad (2017): Psychological Roadblocks to the Adoption of Self-Driving Vehicles. Nature Human Behaviour, Vol. 1, No. 10, https://doi.org/10.1038/s41562-0170202-6.

Surden, Harry - Williams, Mary-Anne (2016): Technological Opacity, Predictability, and Self-Driving Cars. Cardozo Law Review, Vol. 38, No. 121, https:/ /doi.org/10.2139/ssrn.2747491.

Szell, Michael - Ratti, Carlo - Santi, Paolo (2015): Trip Sharing in the Era of Self-driving Cars. Working Paper, NYU.

Takács, Árpád - Rudas, Imre - Bösl, Dominik - Haidegger, Tamás (2018): Highly Automated Vehicles and Self-Driving Cars. IEEE Robotics EF Automation Magazine, Vol. 25, No. 4, https://doi.org/10.1109/ mra.2018.2874301.

Tettamanti, Tamás - Varga, István - Szalay, Zsolt (2016): Impacts of Autonomous Cars from a Traffic Engineering Perspective. Periodica Polytechnica Transportation Engineering, Vol. 44, No. 4, 244-250, https:// doi.org/10.3311/PPtr.9464. 


\section{Banyár József: Az önvezetô autók lehetséges hatásai az életmódra és a gazdaságra}

Thaler, Richard H. - Sunstein, Cass R. (2011): Nudge. Jobb döntések egészségrôl, pénzról és boldogságról - A pénzügyi válság után, Manager Könyvkiadó, Budapest.

The Economist (2012): The Driverless Road Ahead. The Economist, 20 October, www.economist.com/business/2012/10/20/the-driverless-road-ahead.

The Economist (2019): Why Retired People Could Be Ideal Customers for Self-Driving Cars. The Economist, 21 February, www.economist.com/business/2019/02/23/why-retired-people-could-be-ideal-customersfor-self-driving-cars.

Világgazdaság (2018): Magyarország élen jár az önvezetô jármúvek fejlesztésében. Világgazdaság, október 30., www.vg.hu/vallalatok/ipar/magyarorszag-elen-jar-az-onvezeto-jarmuvek-fejleszteseben-1178507/.

Wang, Haiwei et al. (2019): Research on Customer Marketing Acceptance for Future Automatic Driving; A Case Study in China City. IEEE Access, Vol. 7, February, https://doi.org/10.1109/access.2019.2898936.

West, Darrell M. (2016): Moving Forward: Self-driving Vehicles in China, Europe, Japan, Korea, and the United States. Brookings, 20 September.

Williams, Allan F. - Carsten, Oliver (1989): Driver Age and Crash Involvement. American Journal of Public Health, Vol. 79, No. 3, 326-327, https://doi.org/10.2105/ajph.79.3.326.

Wiseman, Yair (2018): In an Era of Autonomous Vehicles, Rails are Obsolete. International Journal of Control and Automation, Vol. 11, No. 2, 151-160, http//dx.doi.org/10.14257/ijca.2018.11.2.13.

Yuan, Yong - Wang, Fei-Yue (2016): Towards Blockchain-based Intelligent Transportation Systems. 2016 IEEE 19th International Conference on Intelligent Transportation Systems (ITSC), 1-4 November. 